\title{
Water consumption patterns of hotels and their response to droughts and public concerns regarding water conservation: The case of the Barcelona hotel industry during the 2007-2008 episode
}

\author{
Marta Dinarès \\ Universitat Autònoma de Barcelona. Departament de Geografia \\ Grup d'investigació INTERFASE en recursos, territoris i paisatges marins i costaners \\ Institut de Ciència i Tecnologia Ambientals (ICTA) \\ marta.dinares@uab.cat

\section{David Saurí} \\ Universitat Autònoma de Barcelona. Departament de Geografia \\ Grup de recerca GRATS en Aigua, Territori i Sostenibilitat \\ Institut de Ciència i Tecnologia Ambientals (ICTA) \\ david.sauri@uab.cat
}

\begin{abstract}
Water supply is a constraining factor in many mass tourist destinations, such as those of the Mediterranean region. Intensifying and increasingly frequent droughts in the context of climate change raise concerns about the sustainability of the tourist sector. Does the hotel sector respond to such concerns, and if yes, how? How do drought episodes affect the adoption of conservation practices and how may adaptive responses differ according to the characteristics of hotel establishments? We survey hotel managers in the Mediterranean city of Barcelona and analyze the annual water consumption of the hotels in the city over a period of 10 years, including four drought events. We find that droughts act as drivers of technological and behavioral change, with the effects being more pronounced in higher star hotels. Drought regulations issued by the government appear to send important signals to the hotel industry, and trigger the adoption of conservation measures. Hotel heterogeneity should be taken into account in future analysis and policy design.
\end{abstract}

Keywords: drought; water consumption; water-conservation measures; hotel industry; Barcelona. 
Marta Dinarès Water consumption patterns of hotels and their response to droughts and public concerns regarding David Saurí water conservation: The case of the Barcelona hotel industry during the 2007-2008 episode

Resum. Els patrons de consum d'aigua dels hotels i la seva resposta a la sequera i a la demanda social per a la conservació d'aigua: el cas de la indústria hotelera de Barcelona durant l'episodi de 2007-2008

El subministrament d'aigua és un factor limitant en moltes destinacions turístiques d'ambient càlid i assolellat, com és el cas de la regió mediterrània. La intensificació i la freqüència dels episodis de sequera, en un context de canvi climàtic, plantegen dubtes sobre la sostenibilitat del sector turístic. Respon, el sector hoteler, a aquests dubtes? I en cas afirmatiu, com? Com afecta la sequera a l'adopció de pràctiques d'estalvi d'aigua? Difereixen les respostes adaptatives d'acord amb les característiques dels establiments hotelers? El present estudi analitza el consum anual d'aigua del sector hoteler de la ciutat mediterrània de Barcelona durant un període de deu anys, incloent-hi quatre esdeveniments de sequera, i n'enquesta els directors. Els resultats mostren que la sequera promou canvis tècnics i de conducta, primordialment en hotels de categoria superior. Els decrets de sequera emesos pel Govern semblen influir en l'adopció de mesures d'estalvi per part de la indústria hotelera. L'heterogeneïtat del sector hoteler és un factor que s'ha de tenir en compte en anàlisis futures i en el disseny de polítiques.

Paraules clau: sequera; consum d'aigua; accions de conservació d'aigua; sector hoteler; Barcelona.

Resumen. Los patrones de consumo de agua de los hoteles y su respuesta ante la sequí y la demanda social de conservación de agua: el caso de la industria hotelera de Barcelona durante el episodio de 2007-2008

El suministro de agua es un factor limitante en muchos destinos turísticos cálidos y soleados, como los de la región del Mediterráneo. La intensificación y la frecuencia de las sequías, en el contexto del cambio climático, plantean dudas acerca de la sostenibilidad del sector turístico. ¿Responde el sector hotelero a esas dudas? Y en caso afirmativo, ¿cómo? ¿Cómo afecta la sequía a la adopción de prácticas de ahorro de agua? ¿Difieren las respuestas adaptativas de acuerdo a las características de los establecimientos hoteleros? El presente estudio analiza el consumo anual de agua del sector hotelero de la ciudad mediterránea de Barcelona durante un período de diez años, incluyendo cuatro episodios de sequía, y encuesta a sus directores. Los resultados muestran que la sequía promueve cambios técnicos y de conducta, primordialmente en los hoteles de categoría superior. Los decretos de sequía emitidos por el Gobierno parecen influir en la adopción de medidas de ahorro. La heterogeneidad del sector hotelero es un factor que debe considerarse en futuros análisis y en el diseño de políticas.

Palabras clave: sequía; consumo de agua; medidas de conservación de agua; sector hotelero; Barcelona.

Résumé. Les modes de consommation de l'eau des hôtels et leur réponse à la sécheresse et à la demande sociale de conservation de l'eau: le cas de l'industrie hôtelière de Barcelone pendant l'épisode de 2007-2008

L'approvisionnement en eau est un facteur limitant dans de nombreuses destinations touristiques chaudes et ensoleillées, comme celles de la région méditerranéenne. L'intensification et la plus grande fréquence des sécheresses, dans le contexte du changement climatique, impliquent des inquiétudes quant à la durabilité du secteur touristique. Le secteur hôtelier répond-il à ces préoccupations, et dans le cas affirmatif, comment? Comment la sécheresse affecte-t-elle l'adoption de pratiques de conservation de l'eau et comment ces réponses 
adaptatives peuvent-elles varier selon les caractéristiques des hôtels? Cette étude analyse la consommation annuelle d'eau du secteur l'hôtelier de la ville méditerranéenne de Barcelone, sur une période de 10 ans comprenant quatre épisodes de sécheresse, et présente l'interview de responsables de ce secteur. Les résultats montrent que la sécheresse permet de développer les changements techniques et comportementaux, principalement pour les hôtels avec le plus d'étoiles. Les décrets de sécheresse émis par le gouvernement semblent influer sur l'adoption de mesures de conservation. L'hétérogénéité du secteur hôtelier est un facteur à considérer dans les analyses futures et la conception des politiques.

Mots-clés: sécheresse; consommation d'eau; mesures de conservation d'eau; secteur hôtelière; Barcelone.

\begin{aligned} & \multicolumn{2}{c}{ Summary } \\ & Introduction Conclusion and implications \\ & Methods for future research \\ & Results and discussion Acknowledgments \\ & Bibliographical references \end{aligned}

\section{Introduction}

Tourism is one of the fastest growing economic sectors worldwide. The sector contributes to global environmental change, and, likewise, it may be affected by this change (Chang and Wong, 2006; González and León, 2001; Gössling, 2002; Molina-Azorín et al., 2009; Gössling et al., 2012a; Scott et al., 2012). Many of the related and supporting activities of tourism depend on the availability and reliability of freshwater resources which may be threatened by climate change in certain areas (Gössling, 2006, 2015; Gössling et al., 2012b; Mensah, 2006; Rico et al., 2009). Destinations without ample and reliable water resources may suffer from drastic declines in tourist arrivals. Therefore, studies on water availability and water management in specific destinations are of critical importance for the tourist sector.

This study focuses on the hotel industry, a key component of the tourism economy (Carmona-Moreno et al., 2004). Hotel operations are characterized by a large number of activities that, individually, may produce small environmental impacts always difficult to identify and regulate, but when taken together, may exert significant pressures on global resources (Bohdanowicz and Martinac, 2007; Gössling, 2002; Kirk, 1995). By staying in a hotel, a tourist uses, on average, about one third more water per day than a local person. Tourist water consumption per capita varies between 100-2000 liters per bed per night, depending fundamentally on the characteristics of services provided by hotels (De Stefano, 2004; EEA, 2003; Gössling, 2002; Gössling et al., 2012a). Hence, water use and management is an important social, political and business issue for the hotel industry (Gössling, 2002, 2006; Vera, 2006; WBCSD, 2006), and water scarcity may represent a constraint for the development of 
Marta Dinarès Water consumption patterns of hotels and their response to droughts and public concerns regarding

tourist activities in arid or semi-arid areas such as the Mediterranean (MolinaAzorín et al., 2009; Rico et al., 2009; Saurí and Llurdés, 2010; Vera, 2006). There is already evidence that water shortages may have negatively affected the tourism sector (see, for example, Kent et al., 2002 for Mallorca in 1995 and Gil-Olcina, 2010 for the 1978 drought in Benidorm).

Recent studies on the environmental components of the hotel industry focus on the application and adoption of environmental management practices (Erdogan and Baris, 2007; Kirk, 1995; Mensah, 2006). Other studies have examined the determinants of environmental innovations (González and León, 2001) and the implementation of environmental management systems (Chan and Wong, 2006). Less has been said, however, about the determinants of resource use-consumption in hotels (Bohdanowicz and Martinac, 2007; Deng, 2003; Trung and Kumar, 2005) and studies that have specifically investigated the relationship between water and the hotel industry are even scarcer (Deng and Burnett, 2002; Gössling, 2006, 2015; Kent et al., 2002; March et al., 2004; Rico et al., 2009; Vera, 2006). These studies tend to be interested in the role of the local water environment on the quality and competitiveness of the tourist product (González and León, 2001) but tend to ignore issues such as water use and the adoption of water saving practices as adaptive responses to climatic phenomena, particularly droughts.

Barcelona provides an interesting case for such an investigation. First, Barcelona is one of the main European tourist destinations (after London, Paris and Rome) and has recently become a major hub for Mediterranean cruises (Garay and Cànoves, 2012). The city is located in a typically Mediterranean region where limited water resources and recurrent drought cycles remain common. In addition, this area is likely to be seriously affected by future climate change, and an increase in the frequency and severity of drought events is expected (IPCC, 2014; Saurí et al., 2013).

In hydrographic terms, Barcelona lies within the so-called Inner Basins of Catalonia, which comprise several Mediterranean rivers such as the Ter and the Llobregat and concentrate more than $90 \%$ of the Catalan population. Approximately 5.5 million people depend for their water on the so-called TerLlobregat system, which includes six dams accounting for a total water storage capacity of about $600 \mathrm{hm}^{3}$.

This system, however, is highly exposed to the vagaries of precipitation since the quantity of water resources available in any normal year roughly equals total demand, and security margins are therefore extremely tight (ACA, 2008a). Security of supply increased with the desalination plant of Barcelona in operation since mid-2009. Before that, however, the system's vulnerability was made evident after several droughts in the late 1990s and 2000s. Thus between 1988 and 2007 six drought alert warnings were issued in the area, leading to the adoption of exceptional measures in order to guarantee water supply. The last drought emergency action was taken in the winter of 2007-2008 by the Catalan regional government, which signed a three-month agreement with several shipping companies to transport water by tanker $\left(1.66 \mathrm{Mm}^{3} / \mathrm{month}\right)$ 
Water consumption patterns of hotels and their response to droughts and public concerns regarding Marta Dinarès water conservation: The case of the Barcelona hotel industry during the 2007-2008 episode

from Tarragona, Marseilles and the Provence Channel (ACA, 2008b; August and Geiger, 2008). Luckily, just after the arrival of the first ship to Barcelona in May 2008, rain came back generously, reservoirs were filled and the likely restrictions for the following autumn were avoided (ACA, 2008c; August and Geiger, 2008).

In parallel with this uncertain situation regarding urban water supply, in 2007-2008 the hotel sector in Barcelona experienced a very important and rapid expansion that had accelerated since 1999, particularly since 2003. With an annual average growth rate of $5.3 \%$ during the period 2003-2008, the hotel infrastructure of Barcelona concentrated in 2008310 establishments, 29,143 rooms and 56,695 beds, with an accumulated increase since 1999 of $78.2 \%$, $86.1 \%$ and $91.8 \%$, respectively (Hotel Occupancy Survey 2008 in Turisme de Barcelona, 2008). However, the distribution of new beds (27,136 units) among the different hotel categories was far from even. Whereas five-star $\left(5 \mathrm{H}^{*}\right)$ and three-star $\left(3 \mathrm{H}^{*}\right)$ hotels had increased by about $5460(20.12 \%)$ and 5902 $(21.75 \%)$ beds, respectively, four-star hotels $\left(4 \mathrm{H}^{*}\right)$ had expanded their activity with 14,260 additional beds (52.55\%).

Regarding water demand, the members of the Association of Barcelona Hotels, representing $84.5 \%$ of the total hotel industry in the city, required $2,747,489 \mathrm{~m}^{3}$ of water annually in 2008 , or 7.63 million liters of water per day (AGBAR, 2009). In 2008, four-star hotels constituted the largest hotel segment in terms of both bed capacity (28,601 beds) (Turisme de Barcelona, 2008 ) and total volume of water consumed $\left(1,379,039 \mathrm{~m}^{3}\right)$ (AGBAR, 2009). On the other hand, $3 \mathrm{H}^{*}$ and $5 \mathrm{H}^{*}$ hotels, though consuming approximately the same amount of water $\left(578,133 \mathrm{~m}^{3}\right.$ and $584,341 \mathrm{~m}^{3}$, respectively, in 2008) (AGBAR, 2009), ranked second (14,032 beds) and third (8487 beds), respectively, in bed capacity (Turisme de Barcelona, 2008).

Around 2008, the hotel industry in Spain was already characterized by comprehensive, though voluntary, environmental actions such as the International Hotels Environmental Initiatives (IHEI), the Green Globe 21 or the International Tourism Partnership working group, among others (Bohdanowicz and Martinac, 2007; Céspedes-Lorente et al., 2003). Nonetheless, it remained relatively insulated from the enforcement of environmental regulations due to lax and sparse national legislation for the tourist sector (Carmona-Moreno et al., 2004; Céspedes-Lorente et al., 2003). In July 2009, however, the Spanish government approved a package of measures, with a budget endowment of over 1.03 billion $€$, to promote sustainability and environmental values within the tourist sector (Capital Madrid, 24/07/2009).

In this context, our main objective is to understand whether and how the industry responded to the drought of 2007-2008 and to the demands for water conservation. In order to accomplish this we will pursue three lines of enquiry. First, we will examine water consumption patterns among the various categories within the hotel industry of Barcelona and test whether droughts had any effect on their water consumption; second, we will assess the relationship between drought and the adoption of water conservation measures; and fina- 
Marta Dinarès Water consumption patterns of hotels and their response to droughts and public concerns regarding

lly, we will analyze the adoption of water conservation measures in the hotel industry and the motives behind this adoption.

\section{Methods}

Our statistical universe was defined as the total number of hotels in the city of Barcelona (310 hotels in 2008). Of this total, we selected those hotels that were members of the Barcelona Hotels Association (hereafter BHA) in June 2009. Therefore, a list of 262 hotels (equivalent to $84.5 \%$ of all hotels) served as the basis for sampling.

We used a triangulation methodology in order to increase the robustness, credibility and validity of the results. The three methods used included: first, data on annual water consumption from 1999 to 2008 of the sampled hotels; second, a 79-item questionnaire addressed to the same hotels; and third, four interviews with either general managers or environmental/maintenance managers of $5 \mathrm{H}^{*}$, $4 \mathrm{H}^{*}, 3 \mathrm{H}^{*}$ and $2 \mathrm{H}^{*}$ hotels, respectively. In addition, the sample identification variables of the first two methodologies were equally defined ('Hotel Category' and 'Year') in order to allow for a comparison between the results of both data sources. Therefore, while validity, credibility and significance of the results were basically supported by the secondary data analysis, the exploratory nature of the questionnaire and the interviews, despite the low response rate, added important insights, thus contributing to the robustness of the results.

Data on annual water consumption for each selected hotel, subsequently classified per hotel category, were obtained under written request from the "Aigües de Barcelona" (AGBAR) water supply company. Prior to the analysis, a first exploratory step for data assessment was performed, and an evaluation of the normality distribution assumptions of the observed values was carried out. Results revealed that the study variables were significantly positively skewed, indicating that normality assumptions were not fulfilled. Therefore, a square root transformation was performed on the original variables to obtain an approximately normal distribution.

For the analysis, a two factor ANOVA was performed using the generalized linear model with repeated measures. Statistical significance was assumed when $\mathrm{p}<0.05$. This procedure allowed modeling the values of a scale-dependent variable measured at multiple time periods; that is, water consumption by hotels from 1999 to 2008 based on its relationships to categorical ('Hotel Category') and scale ('Year') predictors, and the time periods at which it was measured. Hence, the model included two variables ('Hotel Category' and 'Year') with repeated measures in one factor ('Year'; the 'within-subject' factor). The 'Hotel Category' variable was defined as the 'between-subject' factor, which subdivided the sample into discrete groups from $1 \mathrm{H}^{*}$ to $5 \mathrm{H}^{*}$. Besides testing individual factor effects, the effect of factorial interactions on the dependent variable was also analyzed. In result, the proposed model can be expressed as follows:

Square root (water consumption) $=\mathrm{b} 0+\mathrm{b} 1 \bullet$ Hotel Category $+\mathrm{b} 2 \bullet$ Year + b3•(Year*Hotel Category). 
Water consumption patterns of hotels and their response to droughts and public concerns regarding Marta Dinarès water conservation: The case of the Barcelona hotel industry during the 2007-2008 episode

Table 1. Statistical data summary of the two factor ANOVA model

\begin{tabular}{lccc}
\hline \multicolumn{4}{c}{ Tests of Model Effects } \\
\hline \multicolumn{3}{c}{ Source } & Wype III \\
\cline { 2 - 4 } & Wald Chi-Square & df & Sig. \\
\hline (Intercept) & 264.739 & 1 & .000 \\
Hcat & 79.367 & 4 & .000 \\
Year & 32.481 & 9 & .000 \\
Hcat ${ }^{*}$ Year & 99.386 & 36 & .000 \\
\hline
\end{tabular}

Dependent Variable: sqroot_wconsump

Model: (Intercept), Hcat, Year, Hcat * Year

Source: Authors' own elaboration.

Table 1 shows the statistical summary of the two factor ANOVA model. The Wald chi-square test confirmed through statistical significance that both independent variables ('Hotel Category' and 'Year'), as well as the interaction factor ('Year*HotelCategory'), had indeed an effect over the variable 'Water Consumption' by hotel.

The questionnaire was intended to elicit information on when, why and what water conservation measures had been adopted by the establishments, especially in relation to the drought. It included a number of questions on both physical and operational water-use-related factors, as well as motivational factors behind the decision-making process. However, the questionnaire concentrated on the hotel's operational management level and not on the building phase. These two stages have different impacts on the use of resources and the emission of wastes (Bohdanowicz and Martinac, 2007; González and León, 2001). The 79-item questionnaire was divided into six sections: physical characteristics (size, chain affiliation and star category); water-related operational profile and units (number of kitchens, in-house laundry and swimming-pool availability, among others); control and monitoring consumption parameters (number of water meters); water conservation measures (technical and organizational water saving practices, in this section managers were also asked to specify approximately the year in which each of the water-saving practice was adopted); motivational factors behind the decision-making process to adapt water saving practices (in this section respondents were required to choose 5 items from among 11 and subsequently identify the most significant of the five previously selected items); and drought effects on hotel management practices (specific adopted measures, perception on water consumption decrease by customers). Eighty-five percent of the questions were in a single answer format, while the rest were open-ended questions.

The design of the questionnaire was based on the literature on water use and conservation measures (Bohdanowicz, 2005; Bohdanowicz and Martinac, 2007; Carmona-Moreno et al., 2004; De Burgos-Jiménez et al., 2002; Deng and Burnett, 2002; Erdogan and Baris, 2007; González and León, 2001; Mensah, 2006; Molina-Azorín et al., 2009; Trung and Kumar, 2005), as well as 
Marta Dinarès Water consumption patterns of hotels and their response to droughts and public concerns regarding

on existing grey literature on best practices in water management. A first draft was reviewed by experts in water and drought, business management, and the tourism-hospitality sector. In May 2009, the questionnaire was pre-tested with two hotel managers to check for possible ambiguities, misunderstandings, and confusion regarding the terms and questions, and to ensure its comprehension and validity. Some minor adjustments were made before it was finally sent to the target population.

The fieldwork started in June 2009 and lasted about two months. The questionnaire was distributed and sent back through the internal e-mail system of the BHA. Initial replies were received from 13 hotels. A reminder circular sent a week before the deadline slightly increased the number of replies. Some follow-up calls were made afterwards by BHA managers to improve the response rate. After removing incomplete and unusable responses, a total of 27 questionnaires were finally obtained, resulting in a $10.30 \%$ response rate of the total hotel universe. This low response rate can be attributed to the fact that the Spanish hotel industry is generally reticent to answer questions that attempt somehow to disclose evidence of hotel performance, such as annual water consumption or annual occupancy levels (Carmona-Moreno et al., 2004). The respondents sample was also slightly biased in favor of $4 \mathrm{H}^{*}$ and $5 \mathrm{H}^{*}$ hotels and misrepresented the $1 \mathrm{H}^{*}$ and $3 \mathrm{H}^{*}$ categories. Nevertheless, this may not represent such a major drawback insofar as $4 \mathrm{H}^{*}$ and $5 \mathrm{H}^{*}$ hotels are also the most important segments in terms of water consumption. There is also the possibility of a self-selection sample bias by hotels with a stronger commitment to environmental concerns; a fact that has been experienced by other empirical studies conducted in the Spanish hotel industry (Carmona-Moreno et al., 2004; Céspedes-Lorente et al., 2003). Since we must remain cautious about any generalizations on the hotel population, we use triangulation and contextualization within the broader empirical literature on the environmental performance of the hotel industry to sustain some propositions.

Data collected from the questionnaire was first processed using univariate descriptive analysis of frequencies and percentages to characterize the profile of the obtained sample. As said before, it was found that our final database slightly misrepresented one- and three-star hotel categories, and over-represented four- and five-star hotel categories $\left(0 \% 1 \mathrm{H}^{*} ; 11.1 \% 2 \mathrm{H}^{*} ; 14.8 \% 3 \mathrm{H}^{*} ; 63.0 \%\right.$ $4 \mathrm{H}^{*}$ and $\left.11.1 \% 5 \mathrm{H}^{*}\right)$ versus the hotel category distribution of the theoretical population $\left(9.7 \% 1 \mathrm{H}^{*} ; 11.6 \% 2 \mathrm{H}^{*} ; 33.5 \% 3 \mathrm{H}^{*} ; 39.0 \% 4 \mathrm{H}^{*}\right.$ and $6.1 \% 5 \mathrm{H}^{*}$; Turisme de Barcelona, 2008). The same technique was used to explore the level of adoption of the different water-saving practices, as well as to detect the major factors motivating the adoption of these measures. Secondly, cross-tabulation analysis, consisting of a contingency table and a chi-square test for independence, was performed to establish statistically significant differences or associations between the variable 'Hotel Category' and the different factors of the questionnaire. The chi-square test was performed if application conditions were satisfied; alternatively, the likelihood ratio test was used. Likewise, the Kruskal-Wallis test was used for scalar metric variables. Statistical significance was 
tested at the 0.95 level $(\mathrm{p}<0.05)$ in all cases. A statistical analysis of the data from both sources was performed using $\mathrm{SPSS}^{\odot}$ software (PC version 17).

Following the survey, four structured interviews were carried out with either general managers or environmental/maintenance managers of $5 \mathrm{H}^{*}, 4 \mathrm{H}^{*}$, $3 \mathrm{H}^{*}$ and $2 \mathrm{H}^{*}$ hotels, respectively. These interviews were mainly used to gain a deeper understanding of the hotels' water management practices, to corroborate the findings of the questionnaire, and to provide a better and more comprehensive view on some of the issues dealt with in the questionnaire; for example, those regarding the motivational factors behind the adoption of measures as well as sensitivity and awareness towards droughts and climate change.

\section{Results and discussion}

A first result was that both consumption and operational management complexity related to water increased with hotel category. According to authors such as Bohdanowicz and Martinac (2007), Deng and Burnett (2002) and Trung and Kumar (2005), guestrooms, laundries and kitchens are the major water users in a hotel. An example of benchmark figures given at the World Travel Market in London in November 2008 by Hilton Hotels showed that average water usage figures were: $33-35 \%$ in the guestroom, $15-25 \%$ in food and beverage preparation, $5-17 \%$ in laundry, $2-16 \%$ in air conditioning, and $2-15 \%$ in the garden and pool (Simpson, 2008). Erdogan and Baris (2007) further stated that water consumption depends not only on the type, standard and size of a facility, but also on the services provided, climate and irrigation needs, and on existing water conservation practices.

Secondary data on annual water consumption has shown that higher category hotels consume more water annually than lower category hotels, with $5 \mathrm{H}^{*}$ far ahead of the rest. The test of between-subjects effects showed a significance level of $<0.001$ of the critical level associated to the F-statistic, thus indicating that the effect of the 'hotel category' factor over 'water consumption' was indeed significant and that water consumption was uneven across the five hotel categories. This result appears in the profile plot of the 'Hotel Category' factor effect (Fig. 1) showing the increase in water consumption with hotel category. This same result could be seen through the median observation in both the boxplot graphs (Figs. 2, 3, 4) and the median data contained in the summary statistics table (Table 2). As can be seen, water consumption ranges from $1866 \mathrm{~m}^{3}$ for $1 \mathrm{H}^{*}$ to $32,212 \mathrm{~m}^{3}$ for $5 \mathrm{H}^{*}$ in 2008 (approximately seventeen times greater). In short, water consumption is directly and positively related to hotel category.

However, in attempting to characterize the positive relationship between water consumption patterns and category in the Barcelona hotel industry, we needed to examine the descriptive and operational variables included in the first three sections of the questionnaire. A first finding of this analysis was that size was significant for hotel category. The non-parametric Kruskal-Wallis test proved the existence of some differences among the diverse hotel categories 
and their size for the two variables used to measure hotel size: the total area in square meters $(\mathrm{p}=0.016)$, and the total number of beds $(\mathrm{p}=0.047)$. This relationship was further supported by analyzing the statistics of bed capacity of the hotel industry in Barcelona, finding a positive relationship.

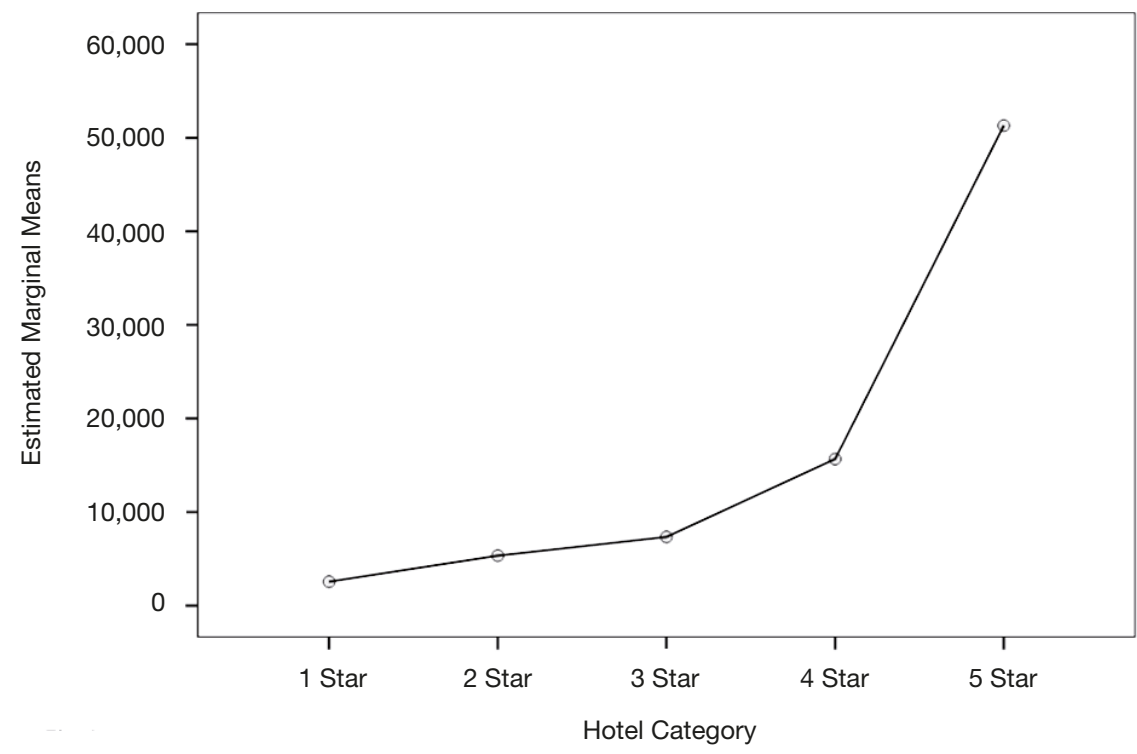

Figure 1. Profile plot of the tests of between-subjects effects displaying the effect of the factor 'Hotel Category' on the dependent variable 'Water Consumption', relationship between size and hotel category.

Source: Authors' own elaboration.

Table 2. Summary statistics of central trend and dispersion measures on annual water consumption data for $1 \mathrm{H}^{*}$ to $5 \mathrm{H}^{*}$ in 1999,2004 and 2008

\begin{tabular}{|c|c|c|c|c|c|c|c|c|c|}
\hline & \multicolumn{3}{|c|}{$1 \mathrm{H}^{*}$} & \multicolumn{3}{|c|}{$2 \mathrm{H}^{*}$} & \multicolumn{3}{|c|}{$3 \mathrm{H}^{*}$} \\
\hline & 1999 & 2004 & 2008 & 1999 & 2004 & 2008 & 1999 & 2004 & 2008 \\
\hline Mean & 2600.5 & 2478.0 & 2386.0 & 5266.3 & 5471.1 & 5672.8 & 6963.4 & 7716.8 & 6732.3 \\
\hline $5 \%$ Trimmed Mean & 2433.3 & 2437.3 & 2275.5 & 5098.3 & 5264.3 & 5533.0 & 6709.4 & 7356.0 & 6464.2 \\
\hline Median & 1931.0 & 2184.0 & 1866.0 & 5721.0 & 4987.0 & 5127.0 & 6509.0 & 6509.0 & 5655.0 \\
\hline \multirow[t]{3}{*}{$\underline{\mathrm{SD}}$} & 2077.3 & 1571.4 & 1744.0 & 3644.3 & 3264.5 & 3263.2 & 4534.8 & 4745.7 & 4131.7 \\
\hline & \multicolumn{3}{|c|}{$4 \mathrm{H}^{*}$} & \multicolumn{3}{|c|}{$5 \mathrm{H}^{*}$} & & & \\
\hline & 1999 & 2004 & 2008 & 1999 & 2004 & 2008 & & & \\
\hline Mean & $15,178.5$ & $16,658.5$ & $14,872.9$ & $55,419.4$ & $56,172.1$ & $46,324.3$ & & & \\
\hline $5 \%$ Trimmed Mean & $14,127.1$ & $14,558.5$ & $12,151.2$ & $52,431.4$ & $50,554.2$ & $42,046.4$ & & & \\
\hline Median & $12,191.5$ & $11,817.5$ & $10,734.5$ & $40,164.0$ & $40,157.0$ & $32,212.0$ & & & \\
\hline SD & $12,412.6$ & $16,980.6$ & $17,554.8$ & $50,807.6$ & $62,259.6$ & $52,259.7$ & & & \\
\hline
\end{tabular}

Source: Authors' own elaboration. 

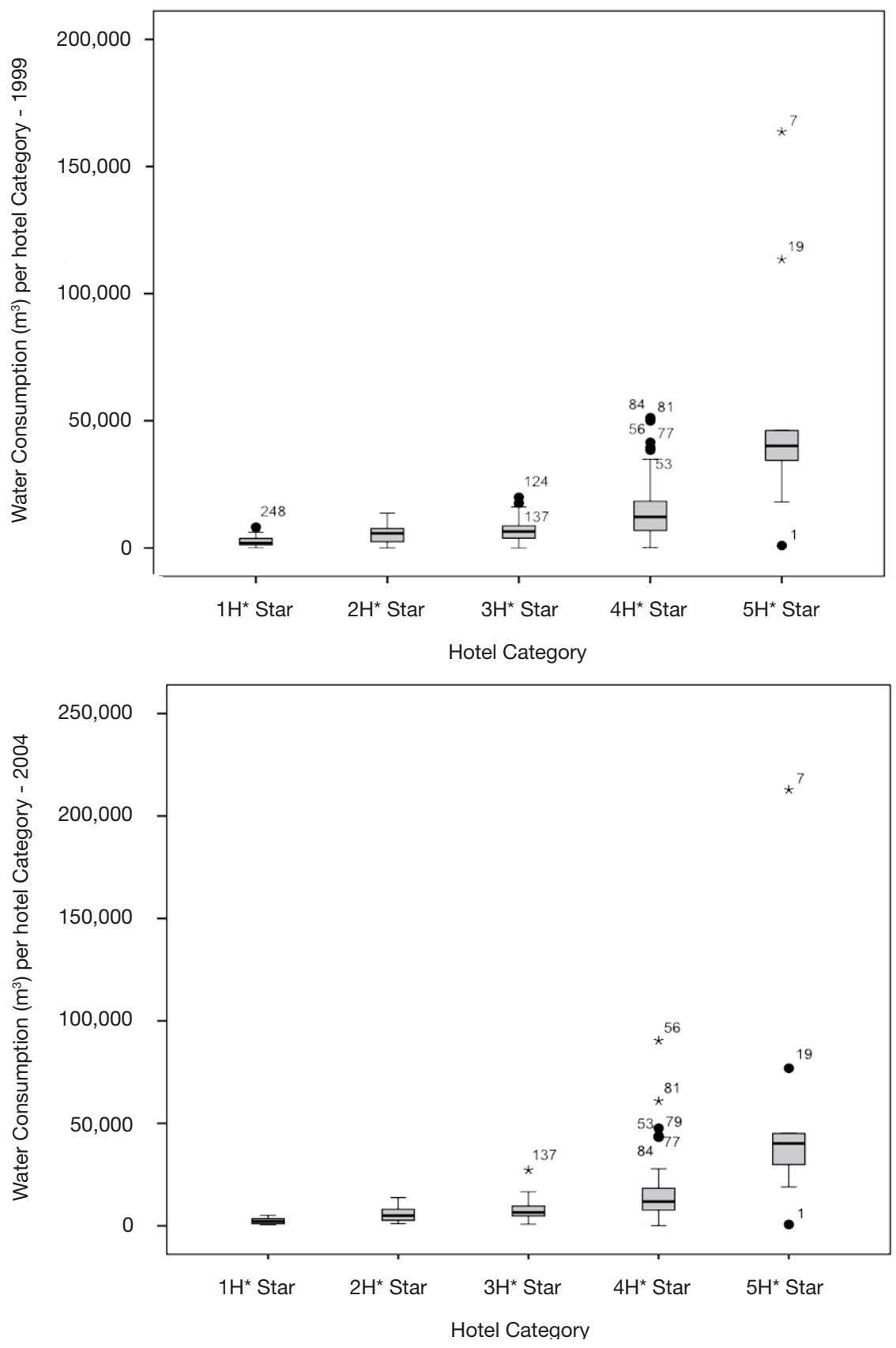

Figure 2-3. Boxplot summary statistics on annual water consumption data value distribution for $1 \mathrm{H}^{\star}$ to $5 \mathrm{H}^{\star}$ in 1999 and 2004.

Source: Authors' own elaboration. 


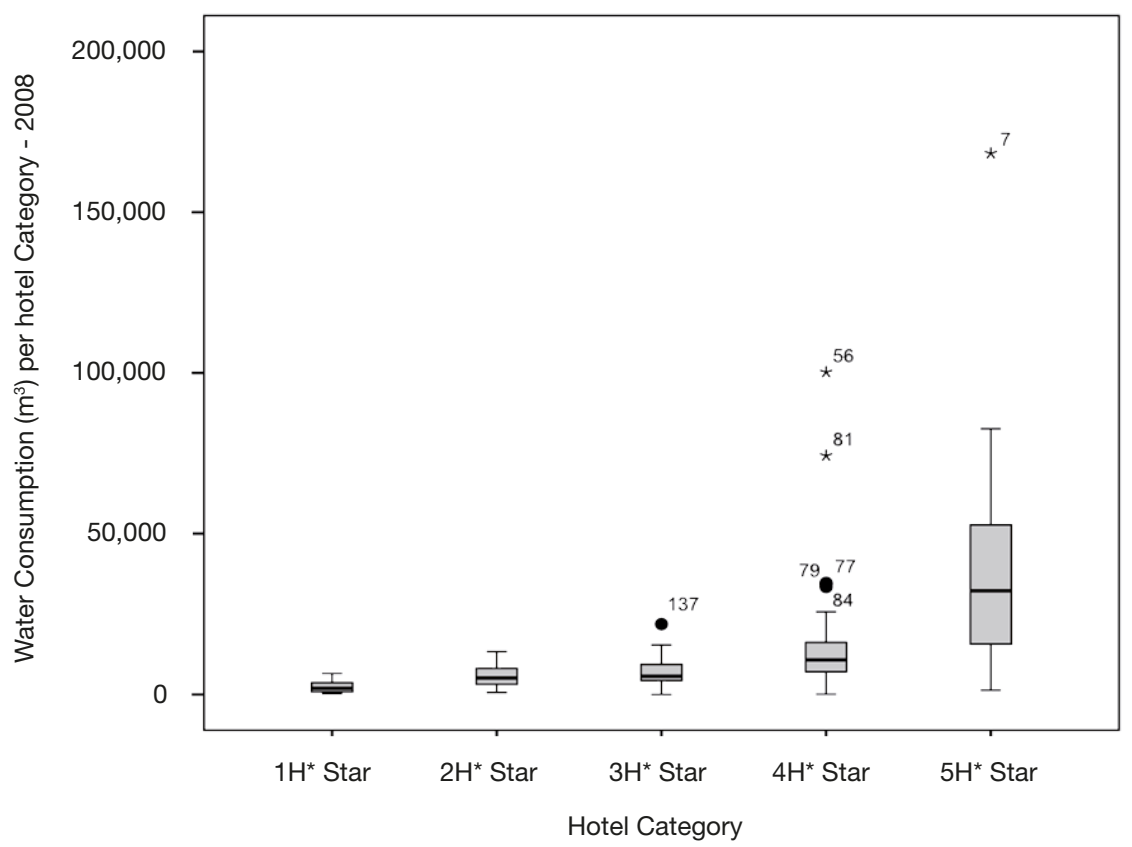

Figure 4. Boxplot summary statistics on annual water consumption data value distribution for $1 \mathrm{H}^{*}$ to $5 \mathrm{H}^{*}$ in 2008.

Source: Authors' own elaboration.

The analysis of operational facilities showed that the outsourcing of laundry was a widespread practice among all hotel categories in Barcelona, with $55.6 \%$ of all hotel respondents completely outsourcing their laundry service. Approximately $37 \%$ did only around $10 \%$ in-house laundry, and only $7.4 \%$ of the hotels did 100\% in-house laundry. Some studies (Deng and Burnett, 2002; Deng, 2003) have shown that water consumption in a hotel building is strongly affected by the presence of an in-house laundry facility and thus recommend processing data by separating hotels with and without in-house laundry facilities. However, in our case and given the low response rate, the hotel data was not processed separately.

As expected, more than $92 \%$ of the hotels surveyed had at least one on-site kitchen and restaurant. Of these, $70.4 \%$ offered full meal service (breakfast, lunch, dinner and bar). Likewise, $70.4 \%$ of the hotels' restaurants were open to both in-house guests and the general public. In this case no statistically significant differences were found regarding the type and/or number of meals offered and hotel category or concerning the type of access allowed. However, the Kruskal-Wallis test showed a statistically significant association between hotel category and the following variables: number of restaurants $(p=0.033)$, number of kitchens $(\mathrm{p}=0.001)$ and number of dishwashers $(\mathrm{p}=0.005)$, showing 
Water consumption patterns of hotels and their response to droughts and public concerns regarding Marta Dinarès

that these variables differed across the various hotel categories. According to their corresponding frequencies, the number of these variables increased with hotel category.

Finally, and with regard to the presence and types of water-intensive facilities, $34.6 \%$ of the hotels had a wellness center, $44.4 \%$ had a swimming pool and $48.1 \%$ offered fitness facilities. Of these, it is worth noting that all affirmative answers belonged to the $4 \mathrm{H}^{*}$ and $5 \mathrm{H}^{*}$ categories, and that all the $5 \mathrm{H}^{*}$ hotels of the sample stated that they had all three water-intensive facilities. Thus, $23.07 \%, 33.3 \%$ and $37 \%$ belonged to the $4 \mathrm{H}^{*}$ category, respectively, while $11.5 \%, 11.1 \%$ and $11.1 \%$ belonged to the $5 \mathrm{H}^{*}$ category, respectively. For each of these three variables, the likelihood ratio test was statistically significant ( $\mathrm{p}<0.05$; equal to $\mathrm{p}=0.006 ; \mathrm{p}=0.004$ and $\mathrm{p}=0.002$, respectively). This showed that the presence of this type of water-intensive facilities increased with the category of the hotel.

Therefore, a positive relationship was found between hotel category and size, the number of restaurants, kitchens and dishwashers, and the presence of water-intensive facilities. Hence, it seems plausible to assume that, as the hotel category increases, so does the water consumption since more water is required to run these facilities (see Table 3).

From the larger variability in the annual water consumption data of high category hotels compared to lower category hotels, it can be deduced that operational water management in hotels becomes more complex with the increase in hotel category. In particular, the summary statistics on the distribution of data values provided by the boxplot exploratory analysis (Figs. 2, 3, 4) indicate that the dispersion of water consumption data increased with the increase in hotel category. In addition, an analysis of each hotel category showed that the water consumption data of low category hotels $\left(1 \mathrm{H}^{*}\right)$ displayed little dispersion and the distribution remained stable along the period studied. Intermediate class hotels $\left(2 \mathrm{H}^{*}\right.$ and $\left.3 \mathrm{H}^{*}\right)$ also showed low data variability and similar annual water consumption distributions, although $3 \mathrm{H}^{*}$ displayed more outlier values in comparison with $2 \mathrm{H}^{*}$, which had none. The upper two hotel categories, $4 \mathrm{H}^{*}$ and $5 \mathrm{H}^{*}$, exhibited higher median water consumption values than the other categories, showed a larger spread of data, and more outliers and extreme cases as well. Furthermore, while the distribution dispersion remained more or less stable within $4 \mathrm{H}^{*}$ over the ten-year period studied, and changes mostly occurred among the different outliers and extreme cases, the variability in the data distribution augmented substantially within the $5 \mathrm{H}^{*}$ group during the years analyzed (Figs. 2, 3, 4 and Table 2).

A plausible explanation of the higher data variability in $4 \mathrm{H}^{*}$ and $5 \mathrm{H}^{*}$ hotels could be their offering of water-intensive facilities, which, moreover, was open not only to in-house guests but also to the general public. Hence, and according to the example indicated by Bohdanowicz and Martinac (2007), for upscale hotels with spa and pool services, the guest-night factor alone would not be significant enough to explain water consumption, because of day-time guests also using these facilities. These authors also note that higher laundry 
Marta Dinarès Water consumption patterns of hotels and their response to droughts and public concerns regarding

Table 3. Characterization of the different hotel categories analyzed

\begin{tabular}{|c|c|c|c|c|c|}
\hline \multicolumn{6}{|c|}{ General aspects. Typology - Characterization of the establishment } \\
\hline & & $2 \mathrm{H}^{*}$ & $3 \mathrm{H}^{*}$ & $4 \mathrm{H}^{*}$ & $5 \mathrm{H}^{*}$ \\
\hline & & Value & Value & Value & Value \\
\hline Total surface of the building/facility & $\mathrm{m}^{2}$ (average) & 2627 & 3690 & \multicolumn{2}{|c|}{769229,500} \\
\hline Total number of hotel beds & Beds (average) & 112 & 136 & 262 & 568 \\
\hline Total hotel staff & Staff (average) & 21 & 24 & 55 & 222 \\
\hline Average hotel stay per customer & Nights per customer (average) & 4 & 2 & 2 & 2 \\
\hline \multicolumn{6}{|c|}{$\begin{array}{l}\text { Operational aspects. Characterization of the production units and services offered by the } \\
\text { hotel and linked to the consumption/ use of water units }\end{array}$} \\
\hline & & $2 \mathrm{H}^{\star}$ & $3 \mathrm{H}^{*}$ & $4 \mathrm{H}^{*}$ & $5 \mathrm{H}^{*}$ \\
\hline & & Value & Value & Value & Value \\
\hline \multirow[t]{2}{*}{ Hotel laundry } & Externalized (\%) & $66.7 \%$ & $100 \%$ & $94 \%$ & \multirow[t]{2}{*}{$100 \%$} \\
\hline & Internalized (\%) & $33.3 \%$ & & $6 \%$ & \\
\hline \multirow[t]{2}{*}{ Access to hotel catering services } & Hotel customers (\%) & $50 \%$ & $50 \%$ & $24 \%$ & \multirow[b]{2}{*}{$100 \%$} \\
\hline & General public (\%) & $50 \%$ & $50 \%$ & $76 \%$ & \\
\hline $\begin{array}{l}\text { Number of hotel areas dedicated } \\
\text { to catering services }\end{array}$ & Number (average) & 1 & 1 & 2 & 3 \\
\hline Number of hotel kitchens & Number (average) & 1 & 1 & 1 & 3 \\
\hline Number of hotel dishwashers & Number (average) & 1 & 1 & 2 & 5 \\
\hline Wellness center service & Yes (\%) & 0 & 0 & $35 \%$ & $100 \%$ \\
\hline Swimming pool service & Yes (\%) & 0 & 0 & $53 \%$ & $100 \%$ \\
\hline Fitness facility & Yes (\%) & 0 & 0 & $59 \%$ & $100 \%$ \\
\hline Garden & Yes (\%) & 0 & $25 \%$ & $24 \%$ & $33 \%$ \\
\hline \multirow[t]{2}{*}{ Number of hotel water meters } & One (\%) & $100 \%$ & $100 \%$ & $82 \%$ & $67 \%$ \\
\hline & More than one (\%) & & & $18 \%$ & $33 \%$ \\
\hline
\end{tabular}

Source: Authors' own elaboration.

per guest-night loads in upscale facilities are partly the result of day-time activities in sport and health centers (offered by some hotels), as well as a varying textile quality/weight of laundry items (i.e., very large towels at spa facilities or gyms). Therefore the determinants of water use for those hotels (total number of food covers served, annual total laundry load, etc.) may not be directly related to their occupancy levels (Bohdanowicz and Martinac, 2007; Deng and Burnett, 2002). Moreover, as remarked by Deng and Burnett (2002), these operational factors are not fully independent and may collectively affect total water use.

The fact that water consumption in upper category hotels involves various end-users suggests a higher complexity of the operational management of water, since explanatory factors other than the guest-occupation levels may play an important role in determining water consumption. These factors need to be identified and their consumption patterns understood. With regard to this last point, mounting evidence shows that operational water management in high category hotels is more complex than in other categories. Data on 
Practices/Measures

Coffee machines with water recirculation system

Pressure reduction of the main hotel's water supply

Water treatment system for hotel's swimming pool

Water-efficient dishwashers

Reuse of bed linen by guest

Water-saving irrigation technologies/system in gardens

Water-efficient washing machines

Reuse of towels by guest

Trained staff and best practice sharing

Involvement of employess in water management

Flushing toilets water reduction systems / Flush toilet water-saving system

Shower head water-saving system/devices

Place advice to key water use points to recommend moderate water consumption to cliens and employees

Tap water-saving systems/devices

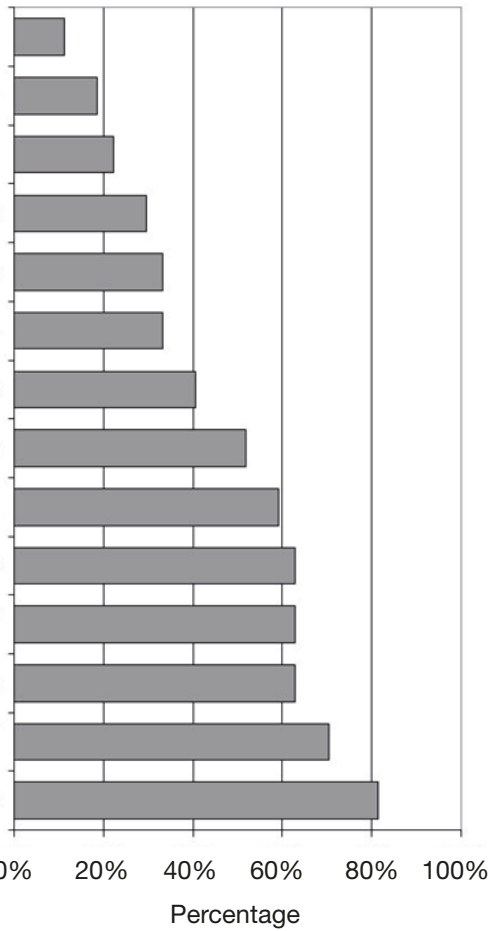

Figure 5. Adoption rates for water-saving measures when year of adoption was specified (in percentage).

Source: Authors' own elaboration.

water control consumption variables showed that not only a low percentage $(18.5 \%)$ of the surveyed hotels had installed more than one (between 2 and a maximum of 5) water meters to better monitor their water uses/major water consuming departments, but also that only $4 \mathrm{H}^{*}$ and $5 \mathrm{H}^{*}$ stated that they had installed more than one water meter. However, no statistical significance was found in this case, since the chi-square test was greater than $\mathrm{p}=0.05 \quad(\mathrm{p}=0.102)$.

Another important finding of our analysis was that the most commonly adopted water conservation measures were those directly related to cost savings. As noted by Carmona-Moreno et al. (2004) and González and León (2001), the environmental attributes of hotel services, such as water, can be managed through a number of operational measures, including both technical and organizational practices. Hence, both practices were included in the questionnaire in order to reflect a balanced combination of the various components of a water management program. Figure 5 shows that the most commonly adopted 
Marta Dinarès Water consumption patterns of hotels and their response to droughts and public concerns regarding

measures to save water were the application of water-saving devices in taps $(81.5 \%)$; the placement of notes at key water consumption points recommending both clients and employees to moderate water use (70.4\%), shower heads and flushing toilet systems (found in 63\% of hotels), employee involvement in water management practices $(63 \%)$, training personnel in the efficient use of water $(59.3 \%)$, and the reuse of towels by guests $(51.9 \%)$. Worthy of note is that four out of the seven most widely adopted measures (water-saving devices in taps, shower heads and dual flush toilets and the reuse of towels by guests, which were implemented by more than $50 \%$ of the hotel respondents) were directly related to achieving greater water use efficiency. This responds to the well-known aim of cutting down overhead costs by firms in order to remain profitable and competitive (González and León, 2001).

This preliminary perception was supported by the analysis of the motivational determinants in the adoption of water-saving practices, where the 'reduction in operating costs' factor, which scored $85.2 \%$, was identified as the factor having the greatest influence in adopting the most common water-saving practices in hotels (see Fig. 6). Likewise, the same factor was chosen by hotel managers as one of the two key factors behind the adoption of water-saving measures (with a score of $25.9 \%$, see black diamond points in Fig. 6). Because of their role in reducing operational and activity costs, the adoption of environmental protection practices has been extensively reported in the literature (Carmona-Moreno et al., 2004; Céspedes-Lorente et al., 2003; Erdogan and Baris, 2007; González and León, 2001).

Furthermore, from data gathered in the drought section of the questionnaire, it was found that $91.6 \%$ of managers who took measures to deal with the drought episode of 2007-2008 stated that they would not forsake these measures once the drought period ended. This is to be expected since the adoption of these water conservation practices resulted in lower hotel water utility bills. Also worth mentioning is that the remaining $8.3 \%$ corresponded to answers from $5 \mathrm{H}^{*}$ and $4 \mathrm{H}^{*}$ that planned to cancel the measures because they had been adopted mainly for swimming pool facilities, whose replenishment had been "prohibited" under drought conditions (El País, 12/5/2008).

The results showed that water conservation measures were adopted particularly after drought warning regulations. In order to enhance the reliability of the answers regarding the adoption of water-saving measures, managers were asked to indicate, approximately, the year in which each measure was adopted. Although the chi-square test did not prove to be significant in the association between water-saving measures and the year of adoption (technical measures, $\mathrm{p}=0.332$; organizational measures, $\mathrm{p}=0.763$ ), it is worth highlighting the results from the frequency analysis (Figs. 7 and 8 ). The most commonly adopted water saving technical devices, taps, shower heads and flushing toilets, were installed by most hotels in 2004, 2006, 2007 and 2008; years which partly coincided with periods of enforced drought warning regulations. Likewise, Figure 8 shows that the three most widely adopted organizational practices, water consumption advice notes ('Advice'), employee involvement ('InvolvWM') 
Factors

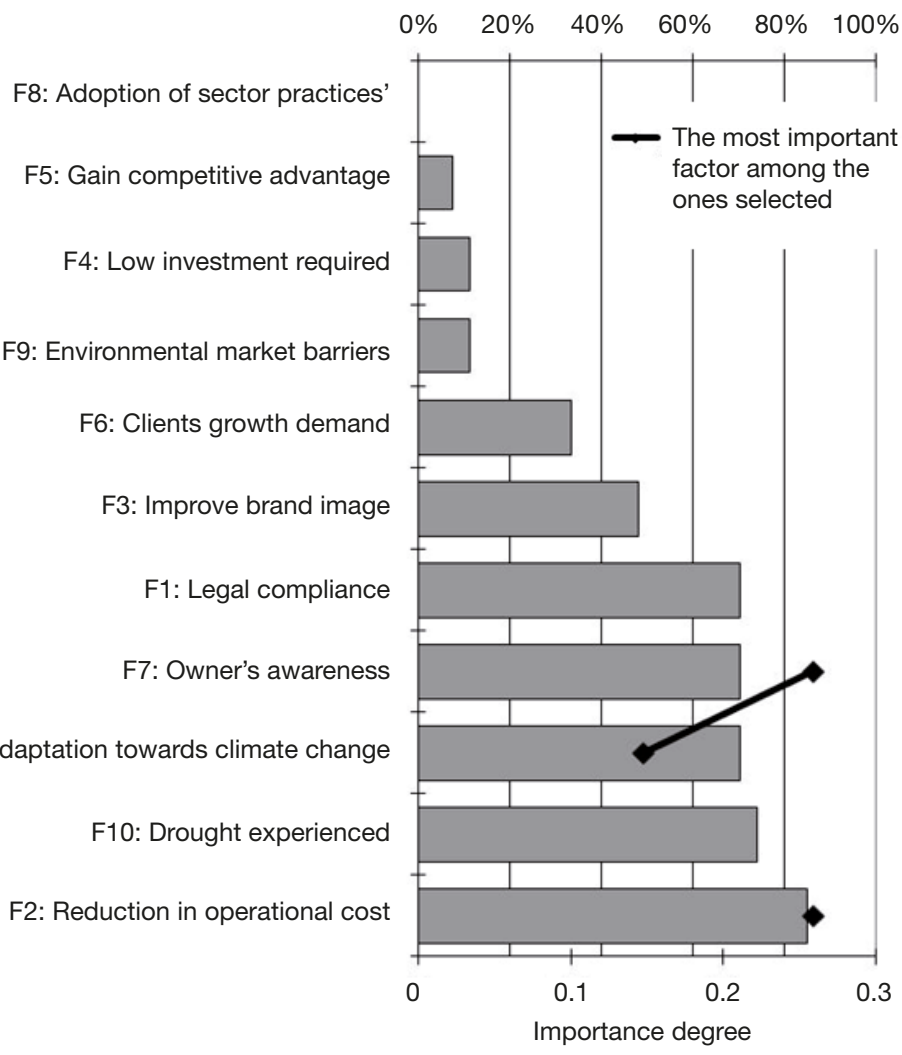

Figure 6. Motivational factors behind the decision-making process to adopt water-saving measures.

Source: Authors' own elaboration.

and staff training in water saving management practices ('Bestpractices') were also enforced by most hotels again in 2004, 2005, 2007 and 2008. Therefore, although not possible to prove it statistically, the observed frequencies of the different measures adopted, linked with their correspondent year of adoption, seem to provide previous evidence of the positive effect of droughts on water conservation. These measures were probably facilitated by the ACA drought warning regulations as well.

The above conclusion is further supported by three more findings. From the analysis of the motivational determinants in the adoption of water saving practices, we first found that 'drought experience' (score 74.1\%) was the second factor exerting the greatest influence on the adoption of the most common water saving practices in hotels (see grey bars in Fig. 6). Second, and with 


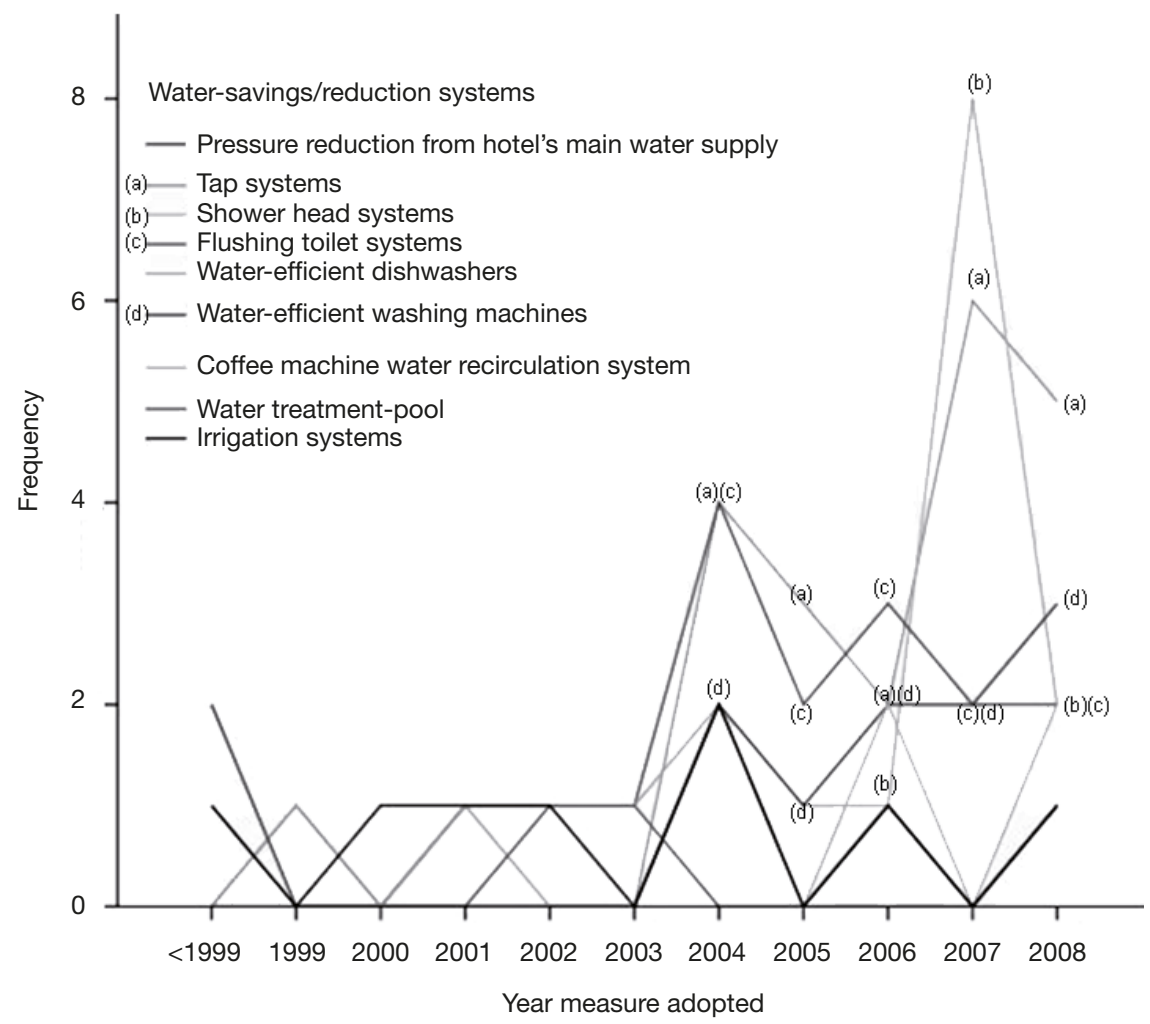

Figure 7. Adoption frequencies for water-saving technical devices and the year of adoption. Source: Authors' own elaboration.

regard to the data gathered from the drought section of the questionnaire, $76.9 \%$ of respondents indicated that they had taken measures to deal with the last drought experienced (2007-2008). This answer matched the results shown in both figures 7 and 8 , according to which the higher adoption rates of the various water-saving measures corresponded to the drought of 20072008. Finally, we must mention that in early 2007 and facing a new problematic water situation, the ACA launched a general awareness campaign in the Barcelona area. This may partly explain the sharp increase in the adoption of both technical and organizational measures during that year (ACA, 2008b; ACA, 2008c).

Secondary data on annual water consumption also supported these conclusions. The profile plot of the 'Year' factor effect (Fig. 9) highlighted the years 2002, 2005, 2006 and 2008 as those in which water consumption decreased in the hotel industry. In addition, water consumption in 2007 was very similar to that of 2002, despite showing an increase in consumption over the previous 


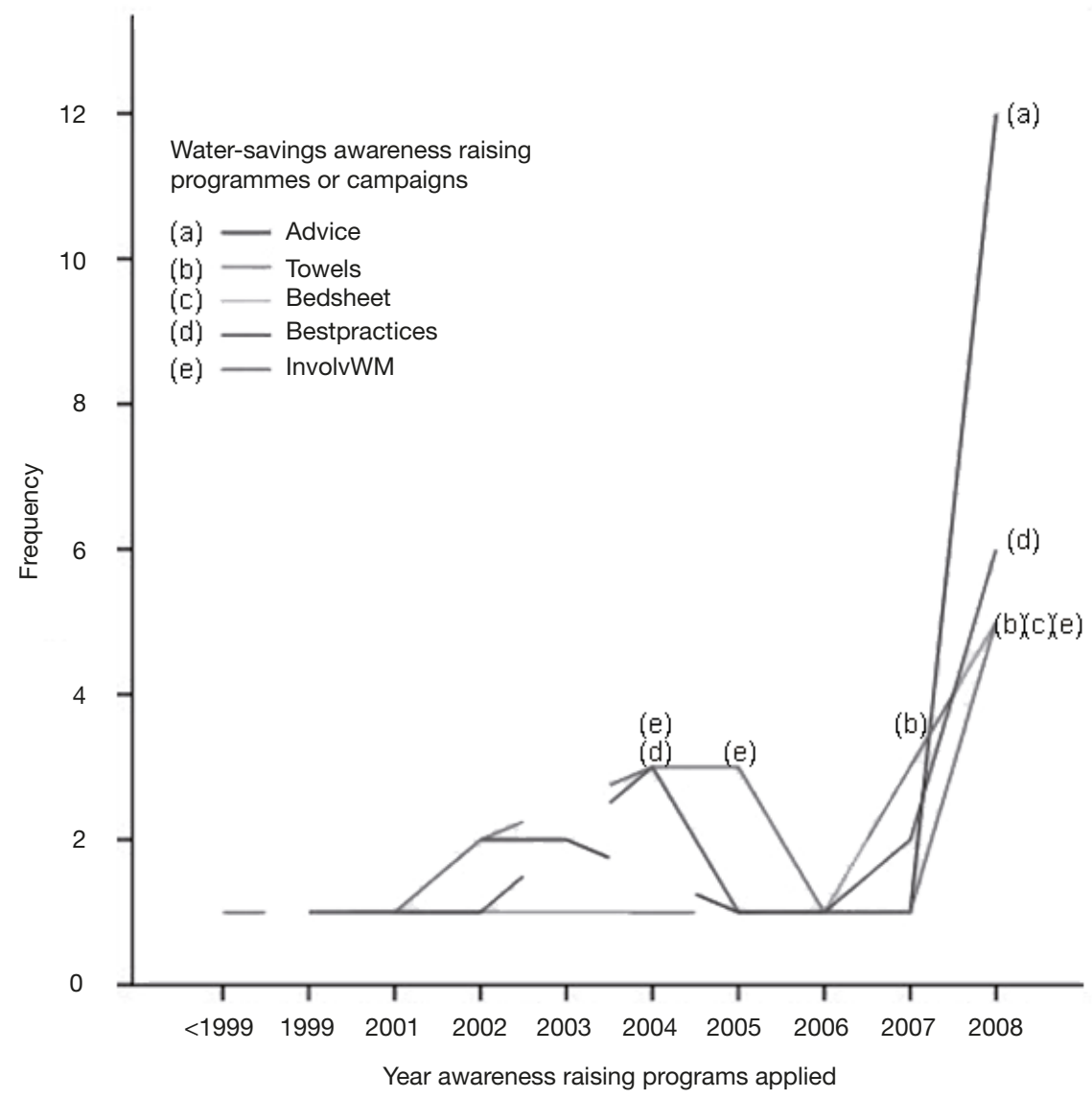

Figure 8. Adoption frequencies for water-saving organizational programs and year of adoption. Source: Authors' own elaboration.

year. Moreover, when comparing the results in Fig. 9 to those in Figs. 7 and 8 showing the technical and organizational water-saving measures adopted by the hotels, it was noted that the years with higher adoption rates of water conservation measures also matched the years in which a larger reduction in water consumption was observed.

This effect of the drought warning regulations is interesting, since as far as hotels were concerned these regulations did not involve any increase in price or mandatory measures other than those applied to municipal or residential users, such as, for example, restrictions on garden irrigation or swimming pools. We may hypothesize that the social pressure exerted by the water emergency situation precipitated the adoption of cost-saving conservation investments by the industry, which were either delayed or ignored during normal, non- 


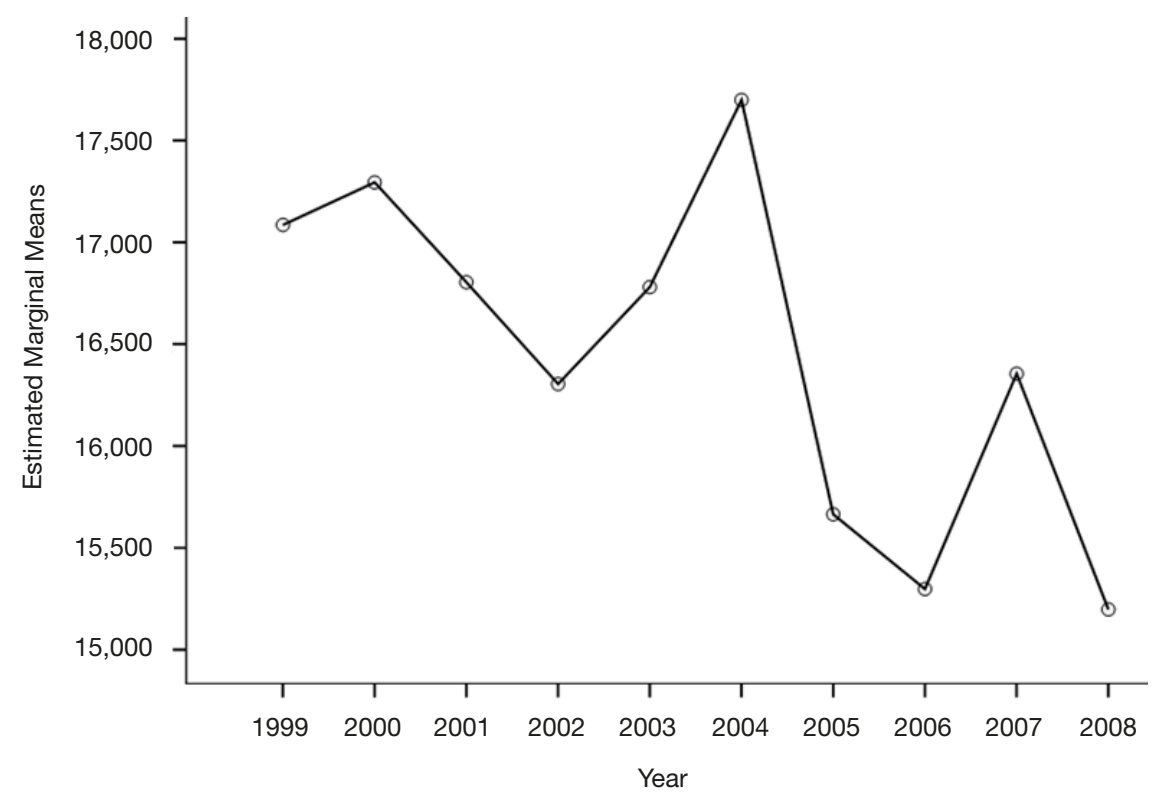

Figure 9. Profile plot of the tests of within-subjects effect displaying the effect of the factor 'Year' on the dependent variable 'Water Consumption'.

Source: Authors' own elaboration.

drought times. Given that prices (and hence cost-saving incentives) did not change significantly before or after the drought, this highlights the crucial role of awareness and social pressure in adopting water conservation measures.

Our analysis also found that drought affects water consumption in different ways depending on hotel category. Using the multifactorial variance model of GLM repeated measures, we examined the effect of factorial interactions on the dependent variable performed by the model. The analysis of the factorial interactions attempted to ascertain whether each combination of factor levels ('Year' and 'Hotel Category') would have a different linear effect on the dependent variable ('Water Consumption'). Theoretically, an interaction is expected between the 'Year' factor and the 'Hotel Category' factor when the independent variable 'Year' affects the dependent variable 'Water Consumption' in a different way depending on the different levels of the independent variable 'Hotel Category'. In our case study, both the within-subjects effects test and the multivariate test performed similarly, obtaining critical levels lower than 0.05 . More specifically, the withinsubjects effect test showed a Sig.<0.05; of 0.013, 0.011 and 0.055; and a Sig. $<0.001$ in all four Multivariate Tests, thus corroborating that a statistically significant effect existed from the interaction 'Year*HotelCategory' factor on the dependent variable 'Water Consumption'. The profile plot (Fig. 10) 


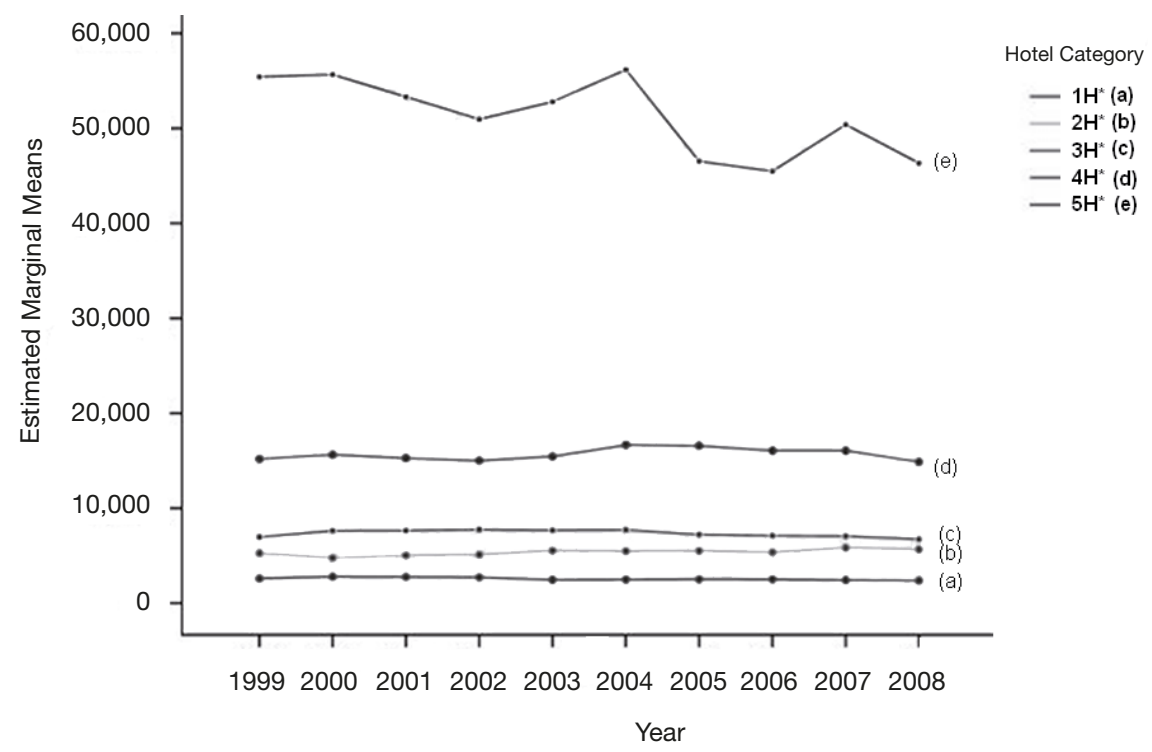

Figure 10. Profile plot of the factorial interaction 'Year*HCategory', with each combination of factor levels showing a different linear effect on the dependent variable 'Water consumption'.

Source: Authors' own elaboration.

displays the differences in water consumption between the five hotel categories analyzed for the various years considered. Whereas the drought effect clearly appears for the $5 \mathrm{H}^{*}$ group, with pronounced decreases in water consumption for the years 2002, 2005, 2006 and 2008 (already identified as drought years), it is less relevant for the $4 \mathrm{H}^{*}$ group and practically negligible for the $3 \mathrm{H}^{*}, 2 \mathrm{H}^{*}$ and $1 \mathrm{H}^{*}$ hotels. For a plausible explanation of this trend we need to remember that the $5 \mathrm{H}^{*}$ group showed the largest variety of water consumption uses, and offered a greater diversity of services and water-intensive facilities, all leading to higher water consumption.

Our analysis does not control for hotel size or occupation. First, data was only for occupation was only available since 2003. Second, and more importantly, simpler data such as water consumption per room or guest can give misleading results, insofar as higher star hotels tend to have a higher "fixed" use of water (i.e., use independent of swimming pool, restaurant or bar occupancy). For higher star hotels, declining occupancy might show up misleadingly as inefficiency (i.e., increasing water consumption per guest), when it is merely the effect of sharing the total water use (variable and fixed) among a smaller number of guests. Nonetheless, and given that overall occupancy in the last six years had increased considerably (in the order of $10 \%$ ) for $5 \mathrm{H}^{*}$ hotels and even more for $4 \mathrm{H}^{*}$ hotels, but remained relatively stable for smaller categories, we may suggest that our fourth finding is relatively robust. 
Marta Dinarès Water consumption patterns of hotels and their response to droughts and public concerns regarding

From our results, we can cautiously propose that higher class hotels are more likely to adopt water-saving measures than the rest. This is reasonable since $5 \mathrm{H}^{*}$ hotels have more water intensive facilities and tend to be larger in size, they use more water to run their daily activities, and thus they have larger margins to reduce consumption when a drought occurs. Figure 10 shows a sustained decrease in water consumption by the $5 \mathrm{H}^{*}$ group category in the ten years studied from $55,419.40 \mathrm{~m}^{3} /$ year per hotel in 1999 to $46,324.30 \mathrm{~m}^{3} /$ year per hotel in 2008, thus representing a $9000 \mathrm{~m}^{3} /$ year decrease per hotel or approximately $16.4 \%$. The evolution for the other hotel categories was: $-2.01 \%$ for $4 \mathrm{H}^{*},-3.32 \%$ for $3 \mathrm{H}^{*} ;+7.72 \%$ for $2 \mathrm{H}^{*}$ and $-8.24 \%$ for $1 \mathrm{H}^{*}$. In light of these results, the sustained downward trend shown by the $5 \mathrm{H}^{*}$ segment - and not found in any other hotel category segment - suggests the possibility that $5 \mathrm{H}^{*}$ hotels adopted relatively more significant water conservation measures and/or practices. We cannot however account for, and rule out, the effects of outsourcing (more likely for higher class hotels). Contracting out big resource-consuming facilities, such as laundries or bars, might show up as a reduction in water use in accounting terms, but may not necessarily translate into improved resource efficiencies.

Our results coincide with those of other empirical studies (González and León, 2001; Mensah, 2006) which have also suggested a relationship between hotel category and level of implementation of environmental management practices. The higher the category of a hotel, the greater the level of investment in environmental management practices. Along with authors such as Carmona-Moreno et al. (2004), Céspedes-Lorente et al. (2003), González and León (2001), Mensah (2006) and Molina-Azorín et al. (2009), we would suggest that as the volume of services provided increases and the scale of operation grows, so does the rate of adoption of environmental actions. Some of the main theoretical arguments used to justify this relationship are: (1) their environmental impact is more substantial in absolute terms, hence it is more visible and as such firms are exposed to greater social and political pressures; (2) these firms have a greater availability of resources to invest in environmental protection; (3) such firms usually implement more formal management practices, and therefore formal environmental management practices; and (4) they may pursue economies of scale.

\section{Conclusion and implications for future research}

This research investigated the relationships between water consumption and management in the hotel industry of Barcelona under a context of drought. We found that higher star hotels are likely to consume more water per establishment, have more complex consumption structures including a variety of water consuming services offered not only to guests but also visitors, and exhibit a high contribution of "fixed" water consumption that does not depend directly on occupancy. Droughts such as that suffered by the city in 2007-2008 
appear to precipitate changes in the behavior of the hotel industry, particularly concerning the adoption of cost-cutting water conservation measures, especially in higher star hotels. Although cost is the main motivation factor for adopting water conservation measures, prices do not appear to be the determining factor in the timing of conservation investments, at least in our case. Social pressures and possibly marketing objectives as well appear to be more important, in particular the awareness fuelled by drought emergency calls by authorities. We also caution against using a single general explanatory model of water use in hotels, since there are important differences and variations among hotel categories. Our results point to the fact that, for upper category hotels, other explanatory factors than guest occupancy levels might play a crucial role in determining water consumption patterns and collectively affect the total water use of the hotel. As said before, water consumption depends not only on the type, standard and size of the facility, but also on the services offered, the climate and existing water conservation practices (Erdogan and Baris, 2007). Hence, since drought and water scarcity elicit different responses according to hotel categories, we may assume that each hotel category would enforce different management policies depending on their operations. Further research should look into the particularities of water consumption patterns, conservation practices and the motivations of different types of hotels in more detail. For example, given the significant differences found in our research, it would be interesting to conduct an in-depth investigation on the similarities and differences of $4 \mathrm{H}^{*}$ and $5 \mathrm{H}^{*}$ hotels in terms of the determinants of water use and management, with special attention to the adopted water-saving measures and to other factors that may not be directly related to hotels' occupancy levels.

This study also provides some policy-relevant insights. First, public programs of support or information can help industries to implement cost-saving water conservation measures in advance; it is not necessary to wait for a drought to act. Second, it is important to design policies that promote the adoption, not only of cost-cutting measures, but also measures that might have longer-term or external benefits, even if they carry higher investment costs. Financial, insurance and gradual repayment incentives have a role to play here. Third, we suggest that different public policy packages and incentives should be designed to target different types of hotel establishments; blanket water conservation policies for the hotel sector as a whole may not be fully effective. Finally, we noted the importance of drought regulations and other forms of social pressure. Given the longer-term impacts mandatory cuts and tougher restrictions might have on prospective visitors' image of the hotel sector, such measures are unlikely to be enforced (unless under extreme drought scenarios). Nonetheless, our study suggests that public authorities could use social pressure as an important leverage upon the hotel industry during drought periods to promote water conservation. Public pressure could, for example, be increased by simple measures such as publishing data about the water consumption of hotel establishments during droughts (e.g., in comparison to past years) or reporting on which hotel has or has not installed efficient appliances. 
Marta Dinarès Water consumption patterns of hotels and their response to droughts and public concerns regarding

This study focused on water conservation measures during hotel operation. Future research could focus on conservation measures incorporated in the design and building phase (for example, the installation of in-house sewage plants, greywater re-use for toilet flushing, rain water for garden irrigation, etc.). The research question here is: does the design of new hotels adapt to droughts and the prospect of climate change, and if so, what differences are there between different types of hotel establishments? If adaptation to climate change is to be effective and the hotel industry to improve its sustainability, longer-term and structural changes will be needed, and not only cost-cutting conservation measures during emergencies, however important these may be.

\section{Acknowledgments}

This article is based on the Master Thesis of Marta Dinarès and has not been sent to any other journal in this version.

We would like to thank both the Barcelona Hotels Association (GHB) and the AGBAR water supply company of Barcelona, who keenly supported and participated in the study. We are also grateful to all the anonymous hotel managers that responded to the questionnaire; they are the reason for and the fundamental root that give sense to this project. Special thanks are extended to the managers for sharing their opinions and valuable insights with us.

We would also like to thank Dr. Uroz and Dr. Lemkow for their valuable help and practical advice, and we are also indebted to Dr. Blasco for her guidance and help on the statistical analysis. Furthermore, we are grateful to the editors of the journal, to Giorgos Kallis and two anonymous reviewers for their helpful and useful comments and suggestions on an earlier version of the manuscript. Finally, we wish to acknowledge the financial support for this research project from the European Consortium of Innovative Universities ECIU.

\section{Bibliographical references}

Agència Catalana de l'Aigua (ACA) (2008a). Water in Catalonia: diagnosis and proposed actions. Significant water management issues raised within the compilation of the River Basin District Management Plan for Catalonia. Agència Catalana de l'Aigua i Departament de Medi Ambient i Habitatge de la Generalitat de Catalunya. Recursos hidràulics-Explotació-Catalunya. Barcelona: Catalan Water Agency. $<$ http://aca-web.gencat.cat/aca/documents/ca/publicacions/aigua_a_catalunya/ aigua_a_catalunya_en.pdf> [accessed online: February 2009].

- (2008b). Evolució de l'Episodi de Sequera 2007/2008. Memòria de Gestió. Taula Nacional de la sequera, 3 de setembre de 2008. Agència Catalana de l'Aigua i Departament de Medi Ambient de la Generalitat de Catalunya. Barcelona: Agència Catalana de l'Aigua. <http://aca-web.gencat.cat/> [accessed online: February 2009].

- (2008c). Agència Catalana de l'Aigua. Planificació, Sequera, gestió de la sequera, premsa. <http://aca-web.gencat.cat/aca/appmanager/aca/aca?_nfpb=true\&_page Label=P1202254461208200370244> [accessed online: April 2009]. 
Water consumption patterns of hotels and their response to droughts and public concerns regarding Marta Dinarès

August, Dorothea and Geiger, Martin (2008). Drought in the Mediterranean. Recent developments. Germany, Frankfurt am Main: World Wildlife Fund for Nature (WWF).

Bohdanowicz, Paulina (2005). "European Hoteliers's Environmental Attitudes: Greening the Business". Cornell Hotel and Restaurant Administration Quarterly, 46(2), 188-204. <http://dx.doi.org/ 10.1177/0010880404273891>

Bohdanowicz, Paulina and Martinac, Ivo (2007). "Determinants and benchmarking of resource consumption in hotels - Case study of Hilton International and Scandic in Europe". Energy and Buildings, 39(1), 82-95. <http://dx.doi.org/ 10.1016/j.enbuild.2006.05.005>

Capital Madrid (24/7/2009). <www.capitalmadrid.info>. [accessed online: January 2010].

Carmona-Moreno, Eva; Céspedes-Lorente, José and De Burgos-Jiménez, Jerónimo (2004). "Environmental strategies in Spanish hotels: contextual factors and performance". The Service Industries Journal, 24(3), 101-130. <http://dx.doi.org/ 10.1080/0264206042000247786>

Céspedes-Lorente, José; De Burgos-Jiménez, Jerónimo and Álvarez-Gil, María José (2003). "Stakeholders' environmental influence. An empirical analysis in the Spanish hotel industry". Scandinavian Journal of Management, 19(3), 333-358. <http://dx.doi.org/ 10.1016/S0956-5221(02)00034-9>

Chan, Eric S.W. and Wong, Simon C.K. (2006). "Motivations for ISO 14001 in the hotel industry". Tourism Management, 27(3), 481-492. <http://dx.doi.org/ 10.1016/j.tourman.2004.10.007>

De Burgos-Jiménez, Jerónimo; Cano-Guillén, Carlos Jesús and CéspedesLoRente, José Joaquín (2002). "Planning and control of environmental performance in hotels". Journal of Sustainable Tourism, 10(3), 207-221. <http://dx.doi.org/ 10.1080/09669580208667163>

De Stefano, Lucia (2004). Freshwater and Tourism in the Mediterranean. Rome: World Wildlife Fund for Nature (WWF) Mediterranean Programme.

Deng, Shi-Ming (2003). "Energy and water uses and their performance explanatory indicators in hotels in Hong Kong". Energy and Buildings, 35(8), 775-784. <http://dx.doi.org/10.1016/S0378-7788(02)00238-4>

Deng, Shi-Ming and Burnett, John (2002). "Water use in hotels in Hong Kong". International Journal of Hospitality Management, 21(1), 57-66. <http://dx.doi.org/10.1016/S0278-4319(01)00015-9>

European Environment Agency (EEA) (2003). Environmental Assessment Report 2003. Copenhaguen: European Environment Agency. <www.eea.europa.eu/publications/environmental_assessment_report_2003_10/kiev_chapt_02_7.pdf> [accessed online: February 2009].

EL PAís (12/5/2008). "El primer barco con agua llega hoy a Barcelona". <www.elpais.com/ articulo/espana/primer/barco/agua/llega/hoy/Barcelona/elpepuesp/20080512 elpepunac_16/Tes> [accessed online: January 22, 2010].

Erdogan, Nazmiye and BARIs, Emin (2007). "Environmental protection programs and conservation practices of hotels in Ankara, Turkey". Tourism Management, 28(2), 604-614. <http://dx.doi.org/10.1016/j.tourman.2006.07.003>

Intergovernmental Panel on Climate Change (IPCC) (2014). Field, Christopher B.; Barros, Vicente R.; Dokken, David Jon; Mach, Katharine J.; Mastrandrea, 
Marta Dinarès Water consumption patterns of hotels and their response to droughts and public concerns regarding

Michael D.; Bilir, T.Eren; Chatterjee, Monalisa; Ebi, Kristie L.; Estrada, Yuka Otsuki; Genova, Robert C.; Girma, Betelhem; Kissel, Eric S.; Levy, Andrew N.; MacCracken, Sandy; Mastrandrea, Patricia R. and White, Leslie L. (eds.). Climate Change 2014: Impacts, Adaptation, and Vulnerability. Part A: Global and Sectoral Aspects. Contribution of Working Group II to the Fifth Assessment Report of the Intergovernmental Panel on Climate Change. Cambridge, United Kingdom and New York, NY, USA: Cambridge University Press.

Garay, Luís Alfonso and Cànoves, Gemma (2012). "Turismo de cruceros en Barcelona. De la marginalidad al liderazgo internacional”. Boletín de la Asociación de Geógrafos Españoles, 60, 253-271.

Gil-Olcina, Antonio (2010). "Optimización de recursos hídricos y armonización de sus usos: el Consorcio de Aguas de la Marina Baja”. Investig Geográficas, 51, 165-183.

González, Matías and León, Carmelo J. (2001). "The adoption of environmental innovations in the hotel industry of Gran Canaria”. Tourism Economics, 7(2), 177-190. <http://dx.doi.org/10.5367/000000001101297801>

GössLing, Stefan (2002). "Global environmental consequences of tourism”. Global Environmental Change, 12(4), 283-302.

<http://dx.doi.org/10.1016/S0959-3780(02)00044-4>

- (2006). "Tourism and water". In: Gössling, Stefan and Hall, C. Michael. (eds.). Tourism \& Global Environmental Change. London: Routledge, 180-194.

- (2015). "New performance indicators for water management in tourism". Tourism Management, 46, 233-244.

<http://dx.doi.org/10.1016/j.tourman.2014.06.018>

Gössling, Stefan; Peeters, Paul; Hall, C. Michael; Dubois, Ghislain; Ceron, JeanPaul; Lehmann, La Vergne and Scott, Daniel. (2012a). "Tourism and water use: supply, demand, and security. An international review”. Tourism Management, 33(1), 1-15.

<http://dx.doi.org/ 10.1016/j.tourman.2011.03.015>

Gössling, Stefan; Scott, Daniel; Hall, C. Michael; Ceron, Jean-Paul and Dubois, Ghislain (2012b). "Consumer behaviour and demand response of tourists to climate change". Annals of Tourism Research, 39(1), 36-58. <http://dx.doi.org/10.1016/j.annals.2011.11.002>

Kent, Martin; Newnham, Rewi and Essex, Stephen (2002). "Tourism and sustainable water supply in Mallorca: a geographical analysis". Applied Geography, 22, 351-374. <http://dx.doi.org/10.1016/S0143-6228(02)00050-4>

KIRK, David (1995). "Environmental management in hotels". International Journal of Contemporary Hospitality Management, 7(6), 3-8. <http://dx.doi.org/10.1108/09596119510095325>

March, Joan G.; Gual, M. and Orozco, F. (2004). "Experiences on greywater reuse for toilet flushing in a hotel (Mallorca Island, Spain)". Desalination, 164(3), 241-247. <http://dx.doi.org/10.1016/S0011-9164(04)00192-4>

Mensah, Ishmael (2006). "Environmental management practices among hotels in the greater Accra region". International Journal of Hospitality Management, 25(3), 414-431. <http://dx.doi.org/10.1016/j.ijhm.2005.02.003>

Molina-Azorín, José F.; Claver-Cortés, Enrique; Pereira-Moliner, Jorge and TARí, Juan José (2009). "Environmental practices and firm performance: an empi- 
rical analysis in the Spanish hotel industry". Journal of Cleaner Production, 17(5), 516-524. $<$ http://dx.doi.org/10.1016/j.jclepro.2008.09.001>

Rico-Amoros, Antonio Manuel; Olcina-Cantos, Jorge and Saurí, David (2009). "Tourist land use patterns and water demand: Evidence from the Western Mediterranean". Land Use Policy, 26(2), 493-501.

$<$ http://dx.doi.org/10.1016/j.landusepol.2008.07.002>

SAurí, David and Llurdés, Joan Carles (2010). "El Turisme”. In: Llebot, J.E. (ed.). Segon Informe sobre el Canvi Climàtic a Catalunya. Barcelona: Generalitat de Catalunya, CADS, 836-871.

Saurí, David; Olcina, Jorge; Vera, José Fernando; Martín-Vide, Javier; March, Hug; Serra-Llobet, Anna and Padilla, Emilio (2013). "Tourism, climate change, and water resources. Coastal Mediterranean Spain as an Example". In: Schmidt-Thomé, P. and Grieving, S. (eds.). European Climate Vulnerabilities and Adaptation. Chichester, UK: Wiley, 199-208.

Scott, Daniel; Gössling, Stefan and Hall, C. Michael (2012). Climate Change and Tourism: Impacts, Adaptation and Mitigation. London: Routledge.

Trung, Do Nam and Kumar, S. (2005). "Resource use and waste management in Vietnam hotel industry". Journal of Cleaner Production, 13(2), 109-116. $<$ http://dx.doi.org/10.1016/j.jclepro.2003.12.014>

Turisme De BARCelona, STATISTICS. (2008). <www.barcelonaturisme.cat/estadistiques> [accessed online: March 2009]

Vera, Fernando J. (2006). "Agua y modelo de desarrollo turístico: la necesidad de nuevos criterios para la gestión de los recursos". Boletín de la Asociación de Geógrafos Españoles, 42, 155-178.

The World Business Council for Sustainable Development (WBCSD) (2006). Business in the world of water: WBCSD water scenarios to 2025. <www.wbcsd.org> [accessed online: March 2009]. 